\title{
Muscle dysmorphia research neglects DSM-5 diagnostic criteria
}

Sebastian S. Sandgren and David Lavallee

This is an Accepted Manuscript of an article published by Taylor \& Francis in Journal of Loss and Trauma on 29th January 2018, available online:

wwww.tandfonline.com/10.1080/15325024.2018.1428484 
Muscle Dysmorphia Research Neglects DSM-5 Diagnostic Criteria

\author{
Author Note \\ Sebastian S. Sandgren \\ Loughborough University, School of Sport, Exercise and Health Sciences, Loughborough \\ Leicestershire, LE11 3TU, UK. \\ David Lavallee
}

Abertay University, School of Social and Health Sciences, Dundee, DD1 1HG, UK.

Please address all correspondence concerning this manuscript to corresponding author Sebastian S. Sandgren. E-mail: S.S.Sandgren@lboro.ac.uk. 


\begin{abstract}
This systematic review aimed to collect, evaluate, and synthesize the research on muscle dysmorphia (MD) post official recognition as a specifier for body dysmorphic disorder (BDD) in the DSM-5, and provide recommendations for future research. Literature searches were conducted in four databases to see if inclusion criteria were met. Results revealed 33 studies meeting inclusion criteria, none of which utilized DSM-5 criteria for MD and/or acknowledged the criterion in their research. Few studies acknowledged the association between MD and BDD, and the methodological quality of recent MD research was considered low due to a lack of clinical samples, measurements not using validated cutoff scores, and the research designs. In conclusion, future MD research is encouraged to utilize DSM-5 diagnostic criteria to better inform clinical practice; and significantly improve the methodological quality. As such, more effective treatment options may be developed reducing the risk of health harming consequences in these individuals.
\end{abstract}

Keywords: systematic review; methodological quality; relationships; body dysmorphic disorder 


\section{Muscle Dysmorphia Research Neglects DSM-5 Diagnostic Criteria}

In western countries, and in particular the United States, research has revealed the mesomorphic (muscular and athletic) and hyper mesomorphic (extreme muscular size and definition) physique to be the most desirable body types amongst males (e.g., Olrich, 1999; Tucker, 1983; Grogan, 2016). From this, such desirable (or unrealistic in some cases) physiques may have accumulated the swift of diagnostic mental disorders focusing on the body. One mental disorder focusing on the body and muscularity is muscle dysmorphia (MD). MD is defined as a preoccupation with muscularity where an individual (predominantly observed in males) sees themselves as not muscular enough or 'too small' even though in many cases these individuals are above average in muscle size and strength (Pope, Katz, \& Hudson, 1993). Such obsessions with the body may become serious clinical disorders, and can result in loss of employment (Pope, Phillips, \& Olivardia, 2000), loss of family and friends (e.g., falling out with people close to you; Olivardia, 2007), or in worst cases result in suicidality and death (Phillips \& Menard, 2006) due to the preoccupation. Initially, MD was termed 'reverse anorexia' due to its explored similarities with anorexia nervosa, where individuals with anorexia nervosa see themselves as bigger and 'fatter' than they really are, and individuals with 'reverse anorexia' see themselves as small and weak when in reality they are large and muscular (Pope et al., 1993). In subsequent years, Pope, Gruber, Choi and Olivardia (1997) suggested MD to be a form of body dysmorphic disorder (BDD), followed by proposed diagnostic criteria for the disorder which has remained more or less unchanged ever since: (1) an individual has a preoccupation with not being sufficiently lean and muscular; (2) the preoccupation with muscularity and leanness causes significant distress or impairment in daily functioning; and (3) the main focus of the preoccupation and behaviours is on perceiving themselves as 'too small' or inadequately muscular. 
From this research, MD was 'born' within the BDD spectrum of psychopathology, and the category BDD is now receiving a great deal of research (e.g., Angelakis, Gooding, \& Panagioti, 2016; Phillips et al., 2010). BDD is classified as a form of 'hypochondriacal disorder' in the somatoform section in the International Statistical Classification of Diseases and Related Health Problems Tenth Edition (ICD-10; World Health Organization, 1992). More recently, BDD was classified under the section of 'Obsessive-Compulsive and Related Disorders' in the Diagnostic and Statistical Manual of Mental Health Disorders Fifth Edition (DSM-5), defined as a preoccupation with perceived appearance defects or flaws (American Psychiatric Association, 2013). In DSM-5, BDD holds the following diagnostic criteria: (1) preoccupation with appearance where an individual is preoccupied with one or more absent or slight defects in their physical appearance (e.g., one or more specific body-parts or muscularity); (2) repetitive and compulsive behaviours related to the concerns with their physical appearance (e.g., constant mirror checking); and (3) the preoccupation must cause impairment or distress in social, occupational or other areas of functioning (e.g., avoids social settings due to the concerns with physical appearance). It has been suggested that a patient who meets all BDD diagnostic criteria should also be evaluated for MD (Pope et al., 2000; Pope et al., 2005).

For the first time, and what can be considered a breakthrough year for MD, the American Psychiatric Association (2013) officially recognized MD as a specifier for BDD under the section of 'Obsessive-Compulsive and Related Disorders' in the DSM-5. In this case, the body, level of muscularity and leanness is the obsession, and the compulsion is the drive and desire to achieve the neccessary levels of muscularity and leanness (Pope et al., 2000). Compulsions (excessive repetitive behaviours) typical to BDD include e.g., mirror checking and reassurance seeking, but excessive weightlifting is more specific to MD providing support for MD being a specifier for BDD (American Psychiatric Association, 
2013). The official recognition of MD in the DSM-5 is a result of the significant amount of research and interest among investigators, which in turn has informed the current official recognition of the diagnostic criteria and classification of MD. However, in the ICD-10, MD is recognized with other BDD conditions in section F45.2, nonetheless the World Health Organisation have decided to exclude MD under the section of BDD in the ICD-11 due to an absence in evidence supporting MD's clinical utility (see Veale \& Matsunaga, 2014).

Expanding on the diagnostic criteria of MD, the research to date has explored relationships associated with the condition, and confirmed the characteristics of an individual with MD. In summary, these characteristics and relationships include an obsession with building more muscle mass (Choi, Pope, \& Olivardia, 2002; Pope et al., 1997; Pope et al., 2000), excessive and compulsive exercise (Leone, Sedory, \& Gray, 2005), appearance checking (e.g., mirror checking) and protection (e.g., wearing baggy clothes to hide physique; Leone et al., 2005; Mosley, 2009), drug abuse (e.g., anabolic androgenic steroids [AAS]; Mosley, 2009; Olivardia, Pope, \& Hudson, 2000), extreme dieting (Leone et al., 2005), impaired daily functioning (e.g., struggling to get daily tasks done such as study or work; Cella, Iannaccone, \& Cotrufo, 2012), depression, anxiety, and high levels of stress (Leone et al., 2005). However, limitations do exist with most studies investigating MD relationships and characteristics, where research participants are only examined on one occasion. As a result, very little is known about temporal aspects (e.g., day-to-day differences) related to the condition, and symptom-stability (e.g., differences in presence of symptoms). At present, only one study has partially studied temporal aspects and symptom-stability in MD. Thomas, Tod and Lavallee (2011) looked at the influence of a training session in young males, and compared MD symptoms on a rest-day and after a training session. They found evidence of that the participants had more symptoms of MD on a rest-day compared to following a training session, indicating that symptoms of MD may be influenced by situational variables. 
With MD comes consequences that may negatively affect day-to-day quality of life, where individuals with MD tend to experience extreme anxiety in the event of missing a workout (Olivardia et al., 2000; Pope et al., 2000). Consequently, daily chores and activities are disrupted because of the obsession with building muscles. Research has shown that individuals with MD have lost their jobs (e.g., the workout schedule interferes with employment working hours; Pope et al., 2000), and loss of family and friends where these relationships are destroyed due to interference with their workout schedules (Olivardia, 2007). These individuals may also possess an extreme attention to diet, calculating all nutritional values, and may find it difficult to eat out with family and friends, fearing this could interrupt maximum muscle growth (Mosley, 2009; Olivardia et al., 2000). In addition, individuals at risk of developing MD (i.e., those not yet meeting full diagnostic criteria), or individuals with MD are also more likely to start using drugs (in particular AAS) to enhance their muscle hypotrophy beyond what is naturally possible (Mosley, 2009; Pope \& Katz, 1994; Pope, Kanayama, Ionescu, \& Hudson, 2004).

Furthermore, some individuals may have a predisposition for developing MD, or experienced e.g., a traumatic event that may contribute to development. Gruber and Pope (1999) suggested that MD may be a reaction to physical abuse as one risk factor in females, where these women want to 'bulk up' for increasing the chance of defending themselves in the event of a future attack. The researchers further suggested that feeling weaker compared to friends and peers, or feeling vulnerable in a hostile environment may contribute to MD development. Individuals with a predisposition of obsessive compulsive disorder symptoms may also be more likely to develop MD (e.g., exercising to build muscle becomes the compulsion in MD cases), and negative childhood or teenage-years eperiences (e.g., bullying or loosing a family member; Pope et al., 2000). Moreover, there are indications in the literature that those who engage in weight training at the gym with the purpose of 
changing/enhancing appearance are more at-risk of developing MD compared to those with performance driven motives (e.g., Murray, Griffiths, Mond, Kean, \& Blashill, 2016; Skemp, Mikat, Schenk, \& Kramer, 2013). Nevertheless, beyond this the literature is rather limited in explaining background and reasons for why some individuals more than others may develop MD (Tod, Edwards, \& Cranswick, 2016).

A significant limitation with the research on MD is the methodological quality, which does not hold a high level, and therefore continues to threat knowledge advancement. Dos Santos Filho et al. (2016) conducted a review amongst 34 studies published between 1997 and 2014, all of which were graded at the lowest level (level IV; National Health and Medical Research Council [NHMRC], 2008) of methodological quality due to research designs (crosssectional and case-series). The NHMRC provide guidelines for levels of evidence, with systematic reviews of level II studies graded at level I evidence (highest level), and crosssectional, single descriptive, and case series designs graded at level IV (within the lowest levels; NHMRC, 2008). Other factors threatening the methodological quality are the use of small samples, poor sample descriptions (e.g., labelling participants 'bodybuilders' when really they are 'non-competitive gym-goers'), large variation in control samples, and nonspecific MD measurements (Tod et al., 2016). Measurements of the sole drive for muscle size (i.e., Drive for Muscularity Scale; McCreary \& Sasse, 2000) do not assess all features associated with MD. Wanting to increase muscle mass or being dissatisfied with level of muscularity is not synonymous with distress (Kimmel \& Mahalik, 2004; Morrison, Morrison, \& McCann, 2006).

Furthermore, prior to MD being officially recognized in 2013 as a specifier for BDD in the DSM-5, the relationship between MD and other types of BDD has received limited research (Phillips et al., 2010). Hitzeroth, Wessels, Zungu-Dirwayi, Oosthhuizen, and Stein (2001) reported 5 of 15 bodybuilders with MD also showed other symptoms of BDD. Further 
studies (e.g., Phillips \& Diaz, 1997; Pope et al., 1997; Pope et al., 2005) have suggested 9.3\% of 193 males, $22.2 \%$ of 63 males, and 25\% of 95 males with BDD also had MD, respectively. Despite strong evidence of MD being a specifier for BDD, authors of more recent research since the turn of the $21^{\text {st }}$ century disagree as to whether MD should be classified as an obsessive-compulsive disorder, BDD, or as an eating disorder (e.g., Maida \& Armstrong, 2005; Mosley, 2009; Murray et al., 2012; Murray, Rieger, Touyz, \& De la Garza García, 2010; Nieuwoudt, Zhou, Coutts, \& Booker, 2012). Murray and Touyz (2012) debate that the phenomenology of MD is markedly different to the features of BDD, such as presentations of BDD do not generally include diet and exercise related psychopathology. Additionally, others argue that the evidence on MD does yet not confirm the validity, nosological classification, and inclusion for MD as a new mental health disorder (e.g., Dos Santos Filho et al., 2016). Out of 34 studies reviewed between 1997 and 2014, only nine of these acknowledged MD as a specifier for BDD, and most did not discuss the nosological status of MD or considered the evidence to be too weak for any psychiatric classification (Dos Santos Filho et al., 2016).

From this research, the diagnostic continuum remains to be further explored to inform clinical practice. Although, the current diagnostic criteria for MD is informative on the characteristics and behaviours associated with the condition, clinical utility is limited with the lack of evidence concerning the degree to which these behaviours and characteristics are existent in pathological presentations (Murray \& Baghurst, 2013). Understanding the present status, research direction, and the needs for improvement in MD research is essential. With this, further support of MD being a specifier for BDD, the methodological quality, background and reasons for individuals developing MD, relationships between MD and other variables, and the consequences of living with the condition, may help show how MD can improve clinical utility and practice. 
With the existing reviews on MD covering the literature up until October 2014 (Dos Santos Filho et al., 2016; Suffolk, Dovey, Goodwin, \& Meyer, 2013), there is now a need for further extension of this knowledge base and reorganizing established knowledge with the release of the DSM-5 on $18^{\text {th }}$ May 2013, and MD being officially recognized as a specifier for BDD that year (American Psychiatric Association, 2013). As such, 2013 may be viewed as a breakthrough year for the disorder, and may have accumulated some changes in the way MD research is now being conducted and understood. Whether or not a substantial change in research on MD is existent post DSM-5, a mutual and global awareness of the state of the research on MD is crucial for researchers in the field, which may lead to advancing knowledge more effectively. Therefore, the aim of this systematic review is to collect, evaluate, and synthesize the research on MD post its official recognition in the DSM-5 related to (a) methodological quality; (b) relationships between MD and other variables; (c) consequences of living with the condition; (d) background and reasons for individuals developing MD; and (e) MD's association with BDD. A second aim is to provide recommendations for future research.

\section{Methods}

\section{Literature Search}

A systematic literature search was performed using the following online electronic EBSCOhost Research Databases up until December 2017: PubMed, MEDLINE, PsycINFO, and SPORTDiscus. The search strategy adopted used the following search terms in ALL FIELDS: muscle dysmorphi* disorder OR muscle dysmorphia OR bigorexia. The search was limited to studies published in 2013 as the oldest and in 2017 as the newest in peer-reviewed scholarly journals only. In addition, manual searches in subject-related journals were conducted to track any neglected studies from the major search strategy. These searches yielded no additional studies to be included. Finally, lists of references from the majority of 
the retrieved studies were screened to trace any additional studies meeting the inclusion criteria for the present systematic review. This search yielded no additional studies to be included.

\section{Inclusion Criteria}

For studies to be included they should have a descriptive or analytical design and report on at least one or more of the following: (1) relationships between MD and other variables; (2) reasons or background for developing or having MD; (3) consequences of living with MD; or (4) provided evidence for the association between MD and BDD with or without utilizing DSM-5 criteria. Studies of all languages were considered for inclusion.

\section{Exclusion Criteria}

Studies submitted and published prior to $18^{\text {th }}$ May 2013 (DSM-5 release date), studies of no original research, theoretical studies, studies utilizing no human samples (e.g., analysing photos in the media), studies validating MD measurements, clinical or applied studies (e.g., case reports), or studies not specifically investigating MD but rather only body dissatisfaction in general or only one feature of MD (e.g., extreme dieting or exercise dependence) were excluded.

\section{Selection Process and Data Extraction}

Once all studies were identified across the included databases, study titles and abstracts were screened for inclusion and exclusion criteria by the first reviewer. The second reviewer consulted the identified studies, and confirmed the studies selected by the first reviewer for eligibility. Studies selected for eligibility were further screened in more detail through full-text screening to identify further inclusion and exclusion of studies (Figure 1). To evaluate the methodological quality of the included studies, country where the research was conducted, study design, measurements employed to participants, and sample characteristics ( $n$, sex, and age) were extracted and synthesised. In addition, study designs were graded 
according to the levels of evidence by the NHMRC (2008) guidelines, although the methodological quality was primarily evaluated based on sample characteristics and measurements employed to the participants in the included studies. Furthermore, studies' main results and/or conclusions were extracted pertaining to at least one or more of the inclusion criteria (see inclusion criteria 1 to 4 ).

\section{Results}

\section{Study Characteristics}

In total, 210 records were identified between January 2013 and December 2017 in PubMed $(n=68)$, Medline - via EBSCO $(n=64)$, PsycINFO $(n=59)$, and SPORTdiscus $(n=$ 19) with some overlap between databases. The screening process revealed 33 studies meeting inclusion criteria (see Figure 1 for the inclusion process). The included studies revealed the following characteristics: they were conducted in Europe $\left(n=11 ; M_{\text {sample size }}=267\right.$ [one study $\operatorname{did}$ not report $n],[63.6 \%]$ male, [36.4\%] mixed gender participants; Spain $\left[n=5 ; M_{\text {sample size }}=\right.$ 356; $60 \%$ male and $40 \%$ mixed gender participants $]$, Italy $\left[n=4, M_{\text {sample size }}=251 ; 66.6 \%\right.$ male and 33.4\% mixed gender participants $]$, Poland $\left[n=1 ; M_{\text {sample size }}=30 ; 100 \%\right.$ mixed gender participants], Germany $\left[n=1 ; M_{\text {sample size }}=100 ; 100 \%\right.$ male participants $]$ ), United States $\left(n=9 ; M_{\text {sample size }}=342[55.5 \%]\right.$ male, $[11.1 \%]$ female, $[33.3 \%]$ mixed gender participants), Australia ( $n=7 ; M_{\text {sample size }}=267[80 \%]$ male, $[20 \%]$ mixed gender participants), United Kingdom $\left(n=3 ; M_{\text {sample size }}=187\right.$ [100\%] male participants $)$, South America $\left(n=2 ; M_{\text {sample size }}=327[50 \%]\right.$ male, $[50 \%]$ mixed gender participants; Brazil $[n=1$; $M_{\text {sample size }}=182 ; 100 \%$ mixed gender participants $]$, Argentina $\left[n=1 ; M_{\text {sample size }}=472 ; 100 \%\right.$ male participants]), and China ( $n=1 ; M_{\text {sample size }}=782[100 \%]$ male participants).

\section{Methodological Quality}

Most studies enrolled non-clinical samples $(n=32 ; 97 \%)$, being physically active university students, weight lifters, gym-goers, athletes, and bodybuilders. One study (Macik 
\& Kowalska, 2015) enrolled a clinical sample of MD diagnosed participants. Other samples consisted of current or recent AAS users (Murray et al., 2016), military personnel (Campagna \& Bowsher, 2016), and personal trainers (Diehl \& Baghurst, 2016). A total of 11 (33.3\%) studies enrolled mixed samples of males and females, 21 (63.6\%) studies enrolled only males, and only 1 study enrolled solitary female participants (Hale, Diehl, Weaver, \& Briggs, 2013). The participants' age ranged from 13-59 years across all studies, although the majority of the studies $(88.6 \%)$ had a minimum age of 18 years for inclusion. Finally, the sample size in the studies ranged from 32-1150 participants, of which the majority (42.4\%) had a sample size between $n=100-200$. Additionally, sample sizes between $n=0-100(18.1 \%)$, between $n=$ 200-500 (15.1\%), and $n=500<(21.2 \%)$ were observed.

The most frequently assessed measures of MD were the Muscle Appearance Satisfaction Scale (MASS; $n=10$ ), Muscle Dysmorphia Inventory (MDI; $n=8$ ) and Muscle Dysmorphic Disorder Inventory (MDDI; $n=7$ ). Other studies also used the Muscle Dysmorphia Questionnaire (MDQ; $n=2$ ), Muscle Dysmorphia Symptom Questionnaire (MDSQ; $n=1$ ), Dysmorphia Concern Questionnaire (DCQ; $n=1$ ), Bodybuilding Dependence Scale (BDS; $n=1$ ), Escala de Satisfacción Muscular (ESM; $n=2)$, Drive for Muscularity Attitudes Questionnaire (DMAQ; $n=1$ ), Drive for Muscularity Scale-Spanish Version (DMS-S; $n=1$ ), for the investigation of MD. In addition, the majority of the included studies also used measures of a variety of mental health disorders and factors associated with MD. Primarily, the Eating Disorder Examination - Questionnaire (EDE-Q; $n=2)$, Eating Attitudes Test -26 (EAT-26; $n=4)$, Exercise Dependence Scale (EDS; $n=1)$, Body Dysmorphic Disorder Questionnaire (BDDQ; $n=1$ ), and Body Dysmorphic Disorder Scale (BDDS; $n=1)$.

Furthermore, most studies had a cross-sectional or survey-based research design $(n=$ $26 ; 78.8 \%$ ), whilst four studies had a descriptive/correlational design, one study had a $2 \times 2 \times 2$ 
between subject design, one study adopted a mixed methods design, and another used an experimental research design. The methodological quality of the majority of the included studies $(78.8 \%)$ were graded at the lowest level (level IV) of quality, consistent with NHMRC (2008) guidelines.

\section{Relationships Between MD and Other Variables}

In total, 24 studies (77.7\% of the total) reported their main significant (significance level of minimum $p<.05)$ relationships between MD symptomatology and a wide range of different variables. These included eating disorder symptoms $(n=5)$, supplements to get more muscular $(n=4)$, body/muscle dissatisfaction $(n=3)$, peer/family influence $(n=3)$, BDD symptoms $(n=2)$, and media influence $(n=2)$. Other less reported relationships with MD were bullying $(n=1)$, bulimia $(n=1)$, drive for thinness $(n=1)$, socially prescribed perfectionism $(n=1)$, distant and close male preferences of muscularity $(n=1)$, negative quality of life $(n=1)$, set shifting difficulties and weak central coherence $(n=1)$, being a student $(n=1)$, body mass index $(\mathrm{BMI} ; n=1)$, stigmatization $(n=1)$, muscle checking $(n=$ $1)$, bodily ideals $(n=1)$, psychopathologic variables $(n=1)$, male body attitudes $(n=1)$, age $(n=1)$, social comparison tendencies/withdrawal $(n=1)$, and upper body clothing $(n=1)$.

\section{Consequences}

Eleven studies (33.3\% of the total) provided data and discussion around the consequences of being at risk of developing MD (those not yet meeting full diagnostic criteria) - or having MD. As a consequence, at risk individuals or individuals with MD may experience: diet and excessive supplement intake $(n=4)$, exercise dependence $(n=2)$, negative self-image $(n=3)$, physique protection ( $n=2$; Baghurst et al. [2014] questions this trait of MD), disordered eating $(n=1)$ poorer quality of life $(n=1)$, and lower desire for social interaction $(n=1)$.

\section{Background and Reasons}


Almost half of the studies ( $n=16 ; 48.5 \%$ of the total) provided evidence for background and reasons for MD development. The most common were: focus on appearance enhancement $(n=2)$, and pre-existing perfectionistic attitudes $(n=2)$. Less common were: AAS use because of appearance related concerns $(n=1)$, perceived female preferences for level of muscularity $(n=1)$, positive beliefs about MD may contribute to development $(n=$ 1), exercise and sport science school enrolment $(n=1)$, perceived ideal physique $(n=1)$, high levels of alexithymia $(n=1)$, non-gender specific in personal trainers $(n=1)$, age-group of 17-19 years $(n=1)$, insecure avoidant attachment style $(n=1)$, stop training $(n=1$; e.g., former weight trainers), self-perception of being too thin or too big $(n=1)$, global psychopathology $(n=1)$, and addicted to working out $(n=1)$.

\section{Associations with BDD}

A total of seven $(21.2 \%$ of the total) studies discussed MD associated - or not - with BDD. None $(n=0)$ of the studies utilized DSM-5 criterion in their research. Three studies (Campagna \& Bowsher, 2016; Macik \& Kowalska, 2015; Nieuwoudt, Zhou, Coutts, \& Booker, 2015) positively associated BDD (DSM-4 criterion utilized) with MD. Two studies neglected BDD criterion, and instead (a) linked MD with anorexia nervosa providing a parallel with eating disorders, and applied the trans-diagnostic model of eating disorders to enhance understanding of MD (Griffiths, Mond, Murray, \& Touyz, 2015); and (b) compared MD with eating disorder psychopathology and confirmed the association (Mitchell et al., 2017). Moreover, two studies also questioned the current proposed MD criteria: Xinhong et al. (2015) suggested MD might have other influential factors other than the ones from BDD and eating disorders, and Nieuwoudt et al. (2016) utilized MD diagnostic criteria by Pope et al. (1997), and BDD DSM-4 criterion, providing evidence to question the acceptance of the proposed MD criteria (see Table 1 for an overview of all results).

\section{Discussion}


This systematic review aimed to collect, evaluate, and synthesize the research on MD post the disorder was recognized as a specifier for BDD in the DSM-5 on the $18^{\text {th }}$ May 2013 relating to several areas. Most significantly, none of the included studies utilized DSM-5 criteria in their research which was an unanticipated finding, and few studies acknowledged MD being associated with BDD. The current systematic review also identified several concerns with the methodological quality of the research on MD. If these concerns are not dealt with, they will continue to substantially limit knowledge advancement in the field. Finally, relationships between MD and other variables, consequences, and background and reasons for MD development have accumulated little advanced knowledge since DSM-5 recognition.

Most studies investigating MD have been conducted in the United States post its literary inception (Dos Santos Filho et al., 2016), however, the present systematic review found that, and according to geographical regions, European countries produced more studies $(n=11)$ compared to that of Unites States $(n=9)$, Australia $(n=7)$, United Kingdom $(n=3)$ South America $(n=2)$, and China $(n=1)$ in recent years post the DSM-5 release. Similar results have been found by Tod et al. (2016), who stated MD has sparked global interest among researchers with the significant amount of non-English publications. Now with this global interest on MD, a logical next step may be cross-cultural comparisons across noticeably different cultures (e.g., United Kingdom and China; Tod et al., 2016). Such data will provide more insight into the cultural differences, which in return may advance knowledge of the societal role in MD development and prevalence. Moreover, the majority (78.8\%) of the included studies were of the lowest level of methodological quality, consistent with NHMRC (2008) guidelines, that is adopting a cross-sectional or survey-based research design. Most studies enrolled non-clinical males aged 18 years or older, and most studies had a sample size between 100-200 participants who were given the measurements MDDI, MDI 
and MASS most frequently across the included studies. Most of these findings are consistent with previous results, with most studies on MD having typically a cross-sectional design, and enrolling non-clinical males labelled 'weightlifters', 'gym-goers', 'students', and 'bodybuilders' (e.g., Dos Santos Filho et al., 2016; Suffolk et al., 2013; Tod et al., 2016). However, Dos Santos Filho et al. (2016) noted that most studies on MD between 1997 and 2014 enrolled samples of less than 100 participants. On the contrary, an increase in sample sizes across the literature in recent years post DSM-5 recognition is observed with most studies enrolling samples of $100-200$ participants (42.4\% of the total) and $500<$ participants (21.2\% of the total).

Methodological quality as well as interpretation of results in MD research is further threatened with the existing MD measures, although valid, limitations exist. For example, not employing these measures with clinical samples, which then limits the discrimination between being 'without MD' and 'with MD' as a consequence, and the measures have no validated cut-off scores (Suffolk et al., 2013). Validating cut-off scores for the available MD measurements will be an important next step, which may advance prevalence reporting using mutual methods in classifying participants as either 'with' or 'without' MD. Additionally, in line with previous findings (Suffolk et al., 2013; Tod et al., 2016), several studies in the present systematic review also employed measures of drive for muscularity (e.g., DMAQ and DMS). Such measurements do not assess all features associated with MD, and therefore results from such studies may be questionable in measuring MD symptomatology as a desire for bigger muscles is not synonymous with distress (Kimmel \& Mahalik, 2004; Morrison et al., 2006). Thus, efforts from researchers in improving the methodological quality on MD research other than increasing sample sizes are called for, as no significant methodological improvements across the literature has been observed for over two decades. 
Most studies in the present systematic review did report one or more relationships between MD and other variables. The most repeated relationships across studies were symptoms of MD correlating with eating disorder symptoms on both total and subscales of MD and eating disorder measures. As such, the association between MD and eating disorder symptomatology is confirmed, but the association needs further investigation with different populations and across genders to determine its significance. Other repeated relationships included e.g., body/muscle dissatisfaction, supplement usage, peer/family influence, and symptoms of BDD. Most of these support earlier findings (e.g., Leone et al., 2005; Olivardia et al., 2000). Exploring relationships are important, yet there is a need to examine these in more depth to strengthen and support the potential significance, and not only to report an association between two variables. More longitudinal data is recommended to further explain a significant relationship (e.g., day-to-day differences).

Eleven studies reported evidence for the consequences for being at risk of developingor having MD, with diet and excessive supplement intake, exercise dependence (i.e., addicted to working out), and negative self-image being the most reported consequences. The findings of these studies are in line with previous research (e.g., Mosley, 2009; Olivardia et al., 2000; Pope et al., 1997). However, for many years physique protection (e.g., hiding one's physique in baggy clothing) has been suggested to be a characteristic and consequence of MD (e.g., Leone et al., 2005; Mosley, 2009). In this systematic review, one of the included studies (Baghurst et al., 2014) questioned physique protection as a characteristic of MD, with function and comfort being the most cited reasons for clothing worn among 114 weight training males. The researchers suggested physique protection as a characteristic of MD needs to be better understood and defined. Although clarification and definition are needed, it is likely that the result would be different if the study utilized males diagnosed with MD or professional bodybuilders, and not collegiate males who regularly workout. Individuals with 
MD or at-risk bodybuilders may associate 'comfortable clothing' with 'covering their physique' more than undiagnosed recreational gym-goers would have, due to stage (e.g., early or late) of development. Physique protection may need to be examined in both clinical and non-clinical populations to draw significant comparisons. In addition, most studies that reported consequences of MD, were studies with a cross-sectional or descriptive design, where these participants were only assessed on one occasion. As such, without prospective studies (e.g., longitudinal), it is difficult to make assumptions about consequences.

Furthermore, almost half of the included studies ( $48.5 \%$ of the total) reported background and reasons for developing MD in individuals. Several factors of background and reasons were reported in singular studies (e.g., self-perception of being too thin or too big, and insecure avoidant attachment style). However, the most repeated were focus on appearance enhancement $(n=3)$, and pre-existing perfectionistic attitudes $(n=3)$. There is now reason to suggest that if the main focus and goal when working out is to enhance appearance due to feeling insufficiently muscular, dissatisfied with current appearance, or having perfectionistic attitudes (e.g., chasing the ideal physique), the chance of developing MD may be higher (e.g., Dryer, Farr, Hiramatsu, \& Quinton, 2016; Murray et al., 2016; Skemp et al., 2013). Additionally, one of the few studies enrolling participants under 18 years of age found that adolescents (17-19 years) had significantly more symptoms of MD compared to 15-16-year-old adolescents (Laghi, Magistro, Guarino, Baumgartner, \& Baiocco, 2013). This result may indicate that one specific age group in teenage years may be particularly vulnerable to symptoms of MD. However, beyond this the literature is limited in providing sufficient evidence of other factors of background and reasons for why some individuals develop MD. This is likely due to the complex mix of neurobiological, evolutionary and sociocultural factors that define the reasons for MD development. 
With MD officially being recognized as a specifier for BDD in the DSM-5, it is likely to think this incredible achievement for the disorder would spark researchers' interest in continuing the investigation of this association to increase MD's clinical utility in the hope of getting MD classified an official clinical disorder. However, this is not the case, and it was detected that none of the studies utilized DSM-5 criterion in their research, and only three studies (Campagna \& Bowsher, 2016; Macik \& Kowalska, 2015; Nieuwoudt et al., 2015) positively associated BDD with MD, using DSM-4 criterion in non-clinical samples. Similarly, out of the 9 studies in Dos Santos Filho et al's. (2016) review that associated MD with BDD, all of these were conducted with non-clinical samples (Cafri, Blevins, \& Thompson, 2006; Cafri, Olivardia, \& Thompson, 2008; Choi et al., 2002; Gruber \& Pope, 1999; Hildebrandt, Alfano, \& Langenbucher, 2010; Hitzeroth et al., 2001; Pope et al., 2005; Soler, Fernandes, Damasceno, \& Novaes, 2013; Wolke \& Sapouna, 2008). Examining the association between MD and BDD in more clinical populations may add to our understanding of MD being a specifier for BDD.

Furthermore, two studies in this review (Griffiths et al., 2015; Mitchell et al., 2017) linked MD with eating disorder psychopathology, and two studies (Nieuwoudt et al., 2016; Xinhong et al., 2015) also questioned the current proposed MD criteria. Hence, the support for MD being a specifier for BDD has limited support in the literature after being recognized in the DSM-5. A detected trend is the attempt to link MD with more eating disorder psychopathology (Griffiths et al., 2015; Mitchell et al., 2017), and the most frequent relationships with MD amongst the included studies in this systematic review were with symptoms of eating disorders. Such attempts have also been reported prior to 2013 (e.g., Murray, et al., 2010; Murray et al., 2012). Even though there is evidence to support the association between BDD and MD (e.g., Hitzeroth et al., 2001; Phillips \& Diaz, 1997; Pope et al., 1997; Pope et al., 2005), more recent research questions the current proposed MD criteria 
(Dos Santos Filho, 2016; Nieuwoudt et al., 2016; Xinhong et al., 2015), and therefore it is suggested that the category MD may need to be re-evaluated for the best fit for diagnostic classification. With research neglecting the DSM-5 diagnostic criteria for MD, this limits the practical applications the research has in informing clinical practice. Because of the wide disagreement around classification amongst researchers, and lack of evidence supporting MD's clinical utility, MD will not be included in the ICD-11 under the section of BDD (Veale \& Matsunaga, 2014).

Despite the issues in the literature on MD, researchers and practitioners in the field are to be acknowledged for their dedication and hard work, which has informed the current diagnostic criteria. With MD being a relatively recently recognized disorder, there is still a long way to go in terms of exploring why some individuals develop the condition and some do not, how this disorder affects one's life, and defining the best classification for MD. A year prior to the release of the DSM-5, Murray and Touyz (2012) argued that MD have similar epidemiological features to eating disorders, and therefore having a better fit with this category than with BDD. To advance knowledge of MD, the research community is advised to reach a more mutual decision on classification (Suffolk et al., 2013). Aiming at associating MD with eating disorders and other related disorders is indeed important for scientific progress in the area. Though, it is just as important to endure investigating the association between MD and BDD, with the diagnostic criteria, as currently stated in the DSM-5.

\section{Future Recommendations}

A second aim of this systematic review was to provide recommendations for future research. Most importantly, researchers are encouraged to utilize the DSM-5 diagnostic criteria for MD in future research, and acknowledge the recognition through further investigation of the association between MD and BDD. As such, more appropriate practical applications may be accumulated, which will inform clinical practice. Moreover, increasing 
and strengthening the methodological quality of the research conducted on MD is called for. Future research should focus more on male as well as female clinical samples in the attempt to discriminate between an individual 'with' and 'without' MD, but also develop and validate cut-off scores for the available MD measurements. With the significant absence of longitudinal data on MD, more research with longitudinal designs are needed (e.g., prospective studies). Examining participants on several occasions over time is recommended to help explain the temporal aspects (e.g., symptom-stability) of the condition as well as help explain the causality of MD.

Also, with the lack of prospective studies of at-risk samples, limited knowledge is known about the consequences of MD and the reasons and background for why some individuals develop MD. Therefore, future research should examine participants over time to advance knowledge of relationships, consequences and background. Furthermore, more qualitative research may increase current understanding on the consequences of living with MD and the background and reasons for development. For example, further in-depth information and real-life examples from males and females with MD will be a major contribution to the literature. Understanding these individuals' own perceptions and the way they live, rather than solely employing 'pen and paper' questionnaires, will advance understanding of the condition significantly. Utilizing qualitative approaches such as focus groups and semi-structured one-on-one interviews, may make it more effective in understanding e.g., underlying mechanisms for why an individual so desperately want bigger muscles, and e.g., classifying an individual with MD using diagnostic criteria, respectively.

Due to the significant lack of studies enrolling participants under 18 years of age and female participants found in the current systematic review, future research may need to focus more on this neglected age group, as well as comparisons between different age groups and 
gender. This might add to the understanding as to why some individuals develop MD at an early age and some do not, and gender-differences across MD psychopathology.

Finally, future research may need to reach a consensus on classification of the disorder, so that advanced treatment options may be developed based on a global scientific agreement. At present, no specific MD intervention has been developed in a randomized control trial, which limits the alternatives for early identification and treatment. Investigators are encouraged to communicate with each other in the attempt to not widen the MD category more than it is today. The wider the category of MD, the less meaningful the category is for defining psychopathology, as debated previously (Suffolk et al., 2013).

\section{Limitations}

The current systematic review has some limitations. A limitation with the investigation of BDD associations with MD is that many of the included studies used MD specific measurements that might have supported the relationship between MD and BDD (i.e., the MDDI grounds on Pope et al's [1997] diagnostic criteria for MD, which in return is supported through the diagnostic criteria for BDD; Hildebrandt, Langenbucher, \& Schlundt, 2004). Furthermore, there might have been an overlap in extracting the major results from the included studies, as relationships, consequences, background and reasons are all interrelated in some way. For example, a reported relationship may have accumulated authors decision to state it a consequence of being at risk of MD or a reason for development.

\section{Conclusion}

MD is an area of research receiving a significant amount of attention and research, and with the disorders breakthrough of official recognition as a specifier for BDD in the DSM-5 in 2013, there is no doubt in that MD is a serious mental disorder assumed to have a negative impact on many peoples' lives. Despite the recognition, and what was an unanticipated finding, was that none of the included studies used the DSM-5 diagnostic criteria for MD in 
their research, and few studies acknowledged the association between MD and BDD, which is concerning. Additionally, with the current low methodological quality of MD research, there is now a significant need for strengthening the methodological quality. If not dealt with, these methodological limitations will continue to substantially limit knowledge advancement and the applications for practitioners and clinicians. Future research is encouraged to utilize the DSM-5 diagnostic criteria for MD, as well as adopt different research designs ranging from one-on-one interviews to large longitudinal studies, recruit other samples than 'non-clinical recreational weightlifters' and of both genders, and validate cut-off scores for MD measurements. As such, future treatment options for MD developed from diagnostic criteria and more robust methodologies, may be more effective in reducing symptomatology, add understanding to the background and reasons for MD development, and assist in preventing the potentially harmful consequences these individuals may experience. 


\section{References}

American Psychiatric Association. (2013). Diagnostic and statistical manual of mental disorders fifth edition (DSM-V). American Psychiatric Pub.

Angelakis, I., Gooding, P. A., \& Panagioti, M. (2016). Suicidality in body dysmorphic disorder (BDD): A systematic review with meta-analysis. Clinical Psychology Review, 49(1), 55-66.

Baghurst, T., Mwavita, M., Volberding, J., Brown, T. C., Murray, S. B., Galli, N., . . Griffiths, S. (2014). Reevaluation of physique protection as a characteristic of muscle dysmorphia. North American Journal of Psychology, 16(3), 575-586.

Bo, S., Zoccali, R., Ponzo, V., Soldati, L., De Carli, L., Benso, A., . . Fassino, S. (2014). University courses, eating problems and muscle dysmorphia: Are there any associations? Journal of Translational Medicine, 12(1), 221-221.

Cafri, G., Blevins, N., \& Thompson, J. K. (2006). The drive for muscle leanness: A complex case with features of muscle dysmorphia and eating disorder not otherwise specified. Eating and Weight Disorders-Studies on Anorexia, Bulimia and Obesity, 11(4), e117-e118.

Cafri, G., Olivardia, R., \& Thompson, J. K. (2008). Symptom characteristics and psychiatric comorbidity among males with muscle dysmorphia. Comprehensive psychiatry, 49(4), 374-379.

Campagna, J. D., \& Bowsher, B. (2016). Prevalence of body dysmorphic disorder and muscle dysmorphia among entry-level military personnel. Military Medicine, 181(5), 494501.

Cella, S., Iannaccone, M., \& Cotrufo, P. (2012). Muscle dysmorphia: A comparison between competitive bodybuilders and fitness practitioners. Journal of Nutritional Therapeutics, 1(1), 12-18. 
Choi, P. Y., Pope, H. G. J., \& Olivardia, R. (2002). Muscle dysmorphia: A new syndrome in weightlifters. British Journal of Sports Medicine, 36(5), 375-376.

Collis, N., Lewis, V., \& Crisp, D. (2016). When is buff enough? the effect of body attitudes and narcissistic traits on muscle dysmorphia. The Journal of Men's Studies, 24(2), 213-225.

Compte, E. J., Sepulveda, A. R., \& Torrente, F. (2015). A two-stage epidemiological study of eating disorders and muscle dysmorphia in male university students in Buenos Aires. International Journal of Eating Disorders, 48(8), 1092-1101.

Danilova, D., Diekhoff, G. M., \& Vandehey, M. A. (2013). A multidimensional scaling analysis of male body perception in men with muscle dysmorphia:" the adonis complex". International Journal of Men's Health, 12(2), 83-106.

Dawes, J., \& Mankin, T. (2004). Muscle dysmorphia. Strength \& Conditioning Journal, 26(2), 24-25.

Diehl, B. J., \& Baghurst, T. (2016). Biopsychosocial factors in drives for muscularity and muscle dysmorphia among personal trainers. Cogent Psychology, 3(1), 1243194.

Dos Santos Filho, Celso Alves, Tirico, P. P., Stefano, S. C., Touyz, S. W., \& Claudino, A. M. (2016). Systematic review of the diagnostic category muscle dysmorphia. Australian \& New Zealand Journal of Psychiatry, 50(4), 322-333.

Dryer, R., Farr, M., Hiramatsu, I., \& Quinton, S. (2016). The role of sociocultural influences on symptoms of muscle dysmorphia and eating disorders in men, and the mediating effects of perfectionism. Behavioral Medicine, 42(3), 174-182.

Fabris, M. A., Longobardi, C., Prino, L. E., \& Settanni, M. (2017). Attachment style and risk of muscle dysmorphia in a sample of male bodybuilders. Psychology of Men \& Masculinity, 47(2), 233-259. 
González-Martí, I., Bustos, J. G. F., Hernández-Martínez, A., \& Jordán, O. R. C. (2014). Physical perceptions and self-concept in athletes with muscle dysmorphia symptoms. Spanish Journal of Psychology, 17(43), 1-7.

González-Martí, I., Fernández-Bustos, J. G., Contreras, J. O., \& Sokolova, M. (2017). Muscle dysmorphia: detection of the use-abuse of anabolic adrogenic steroids in a Spanish sample. Adicciones, 0(0), 853-861.

Griffiths, S., Mond, J. M., Murray, S. B., \& Touyz, S. (2014). Young peoples' stigmatizing attitudes and beliefs about anorexia nervosa and muscle dysmorphia. International Journal of Eating Disorders, 47(2), 189-195.

Griffiths, S., Mond, J. M., Murray, S. B., \& Touyz, S. (2015). Positive beliefs about anorexia nervosa and muscle dysmorphia are associated with eating disorder symptomatology. The Australian and New Zealand Journal of Psychiatry, 49(9), 812-820.

Grogan, S. (2016). Body image: Understanding body dissatisfaction in men, women and children. Taylor \& Francis: New York.

Gruber, A. J., \& Pope, H. G. (1999). Compulsive weight lifting and anabolic drug abuse among women rape victims. Comprehensive Psychiatry, 40(4), 273-277.

Hale, B. D., Diehl, D., Weaver, K., \& Briggs, M. (2013). Exercise dependence and muscle dysmorphia in novice and experienced female bodybuilders. Journal of Behavioral Addictions, 2(4), 244-248.

Hernández-Martínez, A., González-Martí, I., \& Jordán, O. R. C. (2016). Detection of muscle dysmorphia symptoms in male weightlifters. Anales De Psicología/Annals of Psychology, 33(1), 204-210. 
Hildebrandt, T., Alfano, L., \& Langenbucher, J. W. (2010). Body image disturbance in 1000 male appearance and performance enhancing drug users. Journal of psychiatric research, 44(13), 841-846.

Hildebrandt, T., Langenbucher, J., \& Schlundt, D. G. (2004). Muscularity concerns among men: Development of attitudinal and perceptual measures. Body Image, 1(2), 169-181.

Hitzeroth, V., Wessels, C., Zungu - Dirwayi, N., Oosthuizen, P., \& Stein, D. J. (2001). Muscle dysmorphia: A South African sample. Psychiatry and Clinical Neurosciences, 55(5), 521-523.

Kimmel, S. B., \& Mahalik, J. R. (2004). Measuring masculine body ideal distress: Development of a measure. International Journal of Men's Health, 3(1), 1-10.

Laghi, F., Magistro, V., Guarino, A., Baumgartner, E., \& Baiocco, R. (2013). Fattori associati alla dismorfia muscolare in adolescenti gay maschi. Psicologia Clinica Dello Sviluppo, 17(3), 429-448.

Leone, J. E., Sedory, E. J., \& Gray, K. A. (2005). Recognition and treatment of muscle dysmorphia and related body image disorders. Journal of Athletic Training, 40(4), $352-359$.

Leone, J. E., Wise, K. A., Mullin, E. M., Harmon, W., Moreno, N., \& Drewniany, J. (2015). The effects of pubertal timing and alexithymia on symptoms of muscle dysmorphia and the drive for muscularity in men. Psychology of Men \& Masculinity, 16(1), 67-77.

Lin, L., \& DeCusati, F. (2016). Muscle dysmorphia and the perception of men's peer muscularity preferences. American Journal of Men's Health, 10(6), 78-88.

Longobardi, C., Prino, L. E., Fabris, M. A., \& Settanni, M. (2017). Muscle dysmorphia and psychopathology: Findings from an Italian sample of male bodybuilders. Psychiatry research, 256, 231-236. 
Mącik, D., \& Kowalska-Dąbrowska, M. (2015). The risk of muscle dysmorphia and the perception of change in retrospective, current and ideal self-image-preliminary study. Health Psychology Report, 3(1). 24-34.

Maida, D. M., \& Armstrong, S. L. (2005). The classification of muscle dysmorphia. International Journal of Men's Health, 4(1), 73-92.

Martinez Segura, A., Cortes Castell, E., Rizo Baeza, M. M., \& Gil Guillen, V. F. (2015). Evaluation of gym users' diet with muscle dysmorphia (bigorexia). Nutricion Hospitalaria, 32(1), 324-329.

Martinez Segura, A., Rizo Baeza, M. M., Sanchez Ferrer, M., Reig Garcia-Galbis, M., \& Cortes Castell, E. (2014). Relationship between anthropometric variables and muscle dysmorphia in gymnasts in the province of Alicante. Nutricion Hospitalaria, 30(5), 1125-1129.

McCreary, D. R., \& Sasse, D. K. (2000). An exploration of the drive for muscularity in adolescent boys and girls. Journal of American college health, 48(6), 297-304.

Menees, L., Grieve, F. G., Mienaetowski, A., \& Pope, J. (2013). Critical comments about the body and muscle dysmorphia symptoms in collegiate men. International Journal of Men's Health, 12(1), 17-29.

Mitchell, L., Murray, S. B., Hoon, M., Hackett, D., Prvan, T., \& O’Connor, H. (2017). Correlates of muscle dysmorphia symptomatology in natural bodybuilders: Distinguishing factors in the pursuit of hyper-muscularity. Body Image, 22, 1-5.

Morrison, T. G., Morrison, M. A., \& McCann, L. (2006). Striving for bodily perfection? An overview of the drive for muscularity. In M. V. Kindes (Ed.), Body image: New research (pp. 1-34). Hauppauge, NY: Nova Science.

Mosley, P. E. (2009). Bigorexia: Bodybuilding and muscle dysmorphia. European Eating Disorders Review, 17(3), 191-198. 
Murray, S. B., \& Baghurst, T. (2013). Revisiting the diagnostic criteria for muscle dysmorphia. Strength \& Conditioning Journal, 35(1), 69-74.

Murray, S. B., \& Griffiths, S. (2015). Adolescent muscle dysmorphia and family-based treatment: A case report. Clinical Child Psychology and Psychiatry, 20(2), 324-330.

Murray, S. B., Griffiths, S., Mond, J. M., Kean, J., \& Blashill, A. J. (2016). Anabolic steroid use and body image psychopathology in men: Delineating between appearance-versus performance-driven motivations. Drug and Alcohol Dependence, 165(1), 198-202.

Murray, S. B., Rieger, E., Hildebrandt, T., Karlov, L., Russell, J., Boon, E., . . Touyz, S. W. (2012). A comparison of eating, exercise, shape, and weight related symptomatology in males with muscle dysmorphia and anorexia nervosa. Body Image, 9(2), 193-200.

Murray, S. B., Rieger, E., Touyz, S. W., \& De la Garza García, Lic. (2010). Muscle dysmorphia and the DSM - V conundrum: Where does it belong? A review paper. International Journal of Eating Disorders, 43(6), 483-491.

Murray, S. B., \& Touyz, S. W. (2013). Muscle dysmorphia: Towards a diagnostic consensus. Australian and New Zealand Journal of Psychiatry, 47(3), 206-207.

Nabuco, H. C. G., Rodrigues, V. B., Fernandes, V. L. S., de Paula Ravagnani, Fabrício César, Fett, C. A., Espinosa, M. M., \& Ravagnani, Christianne de Faria Coelho. (2016). Factors associated with dietary supplementation among Brazilian athletes. Nutricion Hospitalaria, 33(3), 678-684.

National Health and Medical Research Council. (2008). NHMRC Additional Levels of Evidence and Grades for Recommendations-Stage 2 Consultation. NHMRC. Available at: www.nhmrc.gov.au (accessed 24 October 2017).

Nieuwoudt, J. E., Zhou, S., Coutts, R. A., \& Booker, R. (2015). Symptoms of muscle dysmorphia, body dysmorphic disorder, and eating disorders in a nonclinical 
population of adult male weightlifters in Australia. Journal of Strength and Conditioning Research, 29(5), 1406-1414.

Nieuwoudt, J. E., Zhou, S., Coutts, R. A., \& Booker, R. (2012). Muscle dysmorphia: Current research and potential classification as a disorder. Psychology of Sport and Exercise, 13(5), 569-577.

Nieuwoudt, J. E., Zhou, S., Coutts, R., Booker, R., Yoxall, J., \& Booker, S. (2016). Evaluating the reliability and validity of the proposed muscle dysmorphia criteria. International Journal of Sport and Exercise Psychology, 14(3), 195-209.

Olivardia, R. (2007). Muscle dysmorphia: Characteristics, assessment, and treatment. Thompson, J. Kevin (Ed); Cafri, Guy (Ed). The muscular ideal: Psychological, social, and medical perspectives, (pp. 123-139). Washington, DC, US: American Psychological Association.

Olivardia, R., Pope Jr, H. G., \& Hudson, J. I. (2000). Muscle dysmorphia in male weightlifters: a case-control study. American Journal of Psychiatry, 157(8), 12911296.

Olrich, T. W. (1999). Perceptions of benefits and losses associated with the use and discontinuance of anabolic-androgenic steroids among male bodybuilders. Journal of Personal \& Interpersonal Loss, 4(3), 231-242.

Phillips, K. A., \& Diaz, S. F. (1997). Gender differences in body dysmorphic disorder. Journal of Nervous and Mental Disease, 185(9), 570-577.

Phillips, K. A., \& Menard, W. (2006). Suicidality in body dysmorphic disorder: a prospective study. American Journal of Psychiatry, 163(7), 1280-1282.

Phillips, K. A., Wilhelm, S., Koran, L. M., Didie, E. R., Fallon, B. A., Feusner, J., \& Stein, D. J. (2010). Body dysmorphic disorder: Some key issues for DSM - V. Depression and Anxiety, 27(6), 573-591. 
Pope, C. G., Pope, H. G., Menard, W., Fay, C., Olivardia, R., \& Phillips, K. A. (2005). Clinical features of muscle dysmorphia among males with body dysmorphic disorder. Body Image, 2(4), 395-400.

Pope, H. G. J., Gruber, A. J., Choi, P., Olivardia, R., \& Phillips, K. A. (1997). Muscle dysmorphia. an underrecognized form of body dysmorphic disorder. Psychosomatics, $38(6), 548-557$.

Pope, H. G., Kanayama, G., Ionescu - Pioggia, M., \& Hudson, J. I. (2004). Anabolic steroid users' attitudes towards physicians. Addiction, 99(9), 1189-1194.

Pope, H. G., \& Katz, D. L. (1994). Psychiatric and medical effects of anabolic-androgenic steroid use: A controlled study of 160 athletes. Archives of General Psychiatry, 51(5), 375-382.

Pope, H. G., Katz, D. L., \& Hudson, J. I. (1993). Anorexia nervosa and "reverse anorexia" among 108 male bodybuilders. Comprehensive Psychiatry, 34(6), 406-409.

Pope, H., Phillips, K. A., \& Olivardia, R. (2000). The adonis complex: The secret crisis of male body obsession. Simon and Schuster: New York.

Schneider, C., Agthe, M., Yanagida, T., Voracek, M., \& Hennig-Fast, K. (2017). Effects of muscle dysmorphia, social comparisons and body schema priming on desire for social interaction: an experimental approach. BMC Psychology, 5(1), 19-27.

Skemp, K. M., Mikat, R. P., Schenck, K. P., \& Kramer, N. A. (2013). Muscle dysmorphia: Risk may be influenced by goals of the weightlifter. Journal of Strength and Conditioning Research, 27(9), 2427-2432.

Soler, P. T., Fernandes, H. M., Damasceno, V. O., \& Novaes, J. S. (2013). Vigorexy and levels of exercise dependence in gym goers and bodybuilders. Revista Brasileira De Medicina do Esporte, 19(5), 343-348. 
Suffolk, M. T., Dovey, T. M., Goodwin, H., \& Meyer, C. (2013). Muscle dysmorphia: methodological issues, implications for research. Eating disorders, 21(5), 437-457.

Thomas, A., Tod, D. A., Edwards, C. J., \& McGuigan, M. R. (2014). Drive for muscularity and social physique anxiety mediate the perceived ideal physique muscle dysmorphia relationship. Journal of Strength and Conditioning Research, 28(12), 3508-3514.

Thomas, L. S., Tod, D. A., \& Lavallee, D. E. (2011). Variability in muscle dysmorphia symptoms: The influence of weight training. The Journal of Strength \& Conditioning Research, 25(3), 846-851.

Tod, D., \& Edwards, C. (2015). Relationships among muscle dysmorphia characteristics, body image quality of life, and coping in males. Journal of Science and Medicine in Sport, 18(5), 585-589.

Tod, D., Edwards, C., \& Cranswick, I. (2016). Muscle dysmorphia: current insights. Psychology research and behavior management, 9, 179-188.

Tucker, L. A. (1983). Self-concept: a function of self-perceived somatotype. The Journal of psychology, 113(1), 123-133.

Veale, D., \& Matsunaga, H. (2014). Body dysmorphic disorder and olfactory reference disorder: proposals for ICD-11. Revista brasileira de psiquiatria, 36, 14-20.

Walker, D. C., Anderson, D. A., \& Hildebrandt, T. (2009). Body checking behaviors in men. Body image, 6(3), 164-170.

Wolke, D., \& Sapouna, M. (2008). Big men feeling small: Childhood bullying experience, muscle dysmorphia and other mental health problems in bodybuilders. Psychology of Sport and Exercise, 9(5), 595-604.

World Health Organization. (1992). International Statistical Classification of Diseases and Related Health Problems, 10th Edition (ICD-10). World Health Organization: Geneva. 
Xinhong, J., Yahong, J., Donglin, Y., Xinhao, L., Shuzhi, C., \& Jiaxin, Y. (2015).

Relationships between muscle dysmorphia, body dysphoric disorder, eating disorder and social anxiety in adult chinese male. Journal of TUS, 30(4), 288-291. 
Figure Legends

Figure 1. PRISMA flowchart of the inclusion process in the present systematic review. 
Records identified through database searching $(\mathrm{n}=210)$
Additional records identified through other sources

$$
(\mathrm{n}=0)
$$

مٌ

Records screened

$$
(n=210)
$$

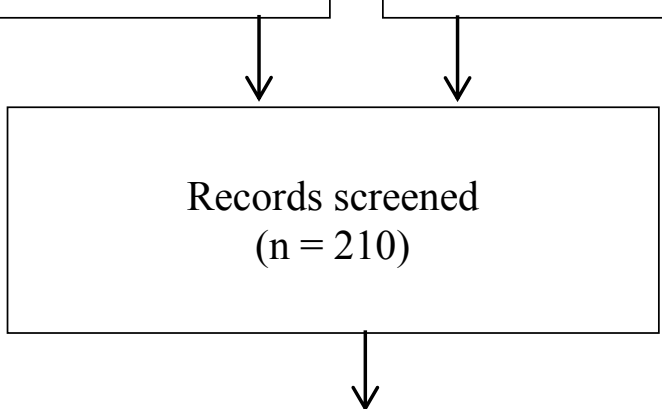

Records excluded:

Not meeting inclusion criteria, no original research or non-specific muscle dysmorphia research* $(n=161)$

Studies included in the present systematic review

$$
(\mathrm{n}=33)
$$

Full-text articles excluded:

Non-specific muscle dysmorphia research*

$$
(\mathrm{n}=3)
$$

Assessed twice for eligibility- or replicated $(\mathrm{n}=4)$

Clinical observation or case report studies $(\mathrm{n}=3)$

Studies submitted and published prior to DSM-V release $(\mathrm{n}=6)$

Figure 1. PRISMA flowchart of the inclusion process in the present systematic review.

* studies examining only one construct of muscle dysmorphia (e.g., solely drive for muscularity or excessive exercise). 


\begin{tabular}{|c|c|c|c|c|c|c|}
\hline \multirow{2}{*}{$\begin{array}{l}\text { Author (year), } \\
\text { country }\end{array}$} & \multicolumn{2}{|c|}{ Methodological quality } & \multicolumn{4}{|c|}{ Results } \\
\hline & $\begin{array}{c}\text { Design } \\
\text { (measures) }\end{array}$ & $\begin{array}{c}\text { Sample }(\mathrm{n}), \text { sex }(\mathrm{M}, \mathrm{F}) \\
\text { Age (years) }\end{array}$ & $\begin{array}{c}\text { Relationships between MD and other } \\
\text { variables }\end{array}$ & Background/reasons & Consequences & $\begin{array}{l}\text { Association with } \\
\text { BDD }\end{array}$ \\
\hline $\begin{array}{l}\text { Nabuco et al. } \\
\text { (2016), Brazil }\end{array}$ & $\begin{array}{l}\text { Cross- } \\
\text { sectional } \\
\text { (BSQ; MASS) }\end{array}$ & $\begin{array}{l}\text { Professional athletes, } \\
\mathrm{M}(83 \%) \text { and } \mathrm{F}(17 \% \\
n=182) \text {. Age range: } 14- \\
59 \text { years }\end{array}$ & $\begin{array}{l}\text { Risk of MD associated with supplement } \\
\text { intake }(p<0.001)\end{array}$ & & & \\
\hline $\begin{array}{l}\text { Murray et al. } \\
\text { (2016), United } \\
\text { Kingdom }\end{array}$ & $\begin{array}{l}\text { Cross- } \\
\text { sectional } \\
\text { (MDDI; EDE- } \\
\text { Q) }\end{array}$ & $\begin{array}{l}\text { Current or recent AAS } \\
\text { users, M }(n=122) . \text { Age: } \\
29.40 \pm 7.11 \text { years }\end{array}$ & $\begin{array}{l}\text { MD was strongly positively correlated } \\
(p<0.001) \text { with ED (total and subscales) }\end{array}$ & $\begin{array}{l}\text { M whose AAS use is driven by } \\
\text { appearance-related concerns may } \\
\text { be a particularly dysfunctional } \\
\text { subgroup }\end{array}$ & & \\
\hline $\begin{array}{l}\text { Dryer et al. } \\
(2016) \text {, } \\
\text { Australia }\end{array}$ & $\begin{array}{l}\text { Cross- } \\
\text { sectional } \\
\text { (MDQ; EDI-3; } \\
\text { MPS; SFQ) }\end{array}$ & $\begin{array}{l}\text { Non-clinical physically } \\
\text { active M's, }(n=158) \\
\text { Age: } 26.94 \pm 5.50 \\
\text { years }\end{array}$ & $\begin{array}{l}\text { MD was significantly }(p<0.01) \\
\text { correlated with media and peer } \\
\text { influence, teasing, bulimia, BD, DFT, } \\
\text { and SPP }\end{array}$ & $\begin{array}{l}\text { Vulnerability to MD and ED } \\
\text { depend on pre-existing } \\
\text { perfectionistic attitudes, particularly } \\
\text { that of SPP }\end{array}$ & & \\
\hline $\begin{array}{l}\text { Campagna \& } \\
\text { Bowsher } \\
(2016) \text {, } \\
\text { United States }\end{array}$ & $\begin{array}{l}\text { Survey-based } \\
\text { (MDSQ; } \\
\text { DCQ; DSS) }\end{array}$ & $\begin{array}{l}\text { Military personnel } \\
(n=1150), 62.8 \% \text { were } \\
\text { M and } 32.9 \% \mathrm{~F} . \text { Age: } \\
21.8 \pm 4.0 \text { years }(\mathrm{M}) \\
22.2 \pm 4.4 \text { years }(\mathrm{F})\end{array}$ & $\begin{array}{l}\text { Significant strong correlation between } \\
\text { having BDD and using supplements to } \\
\text { get thinner and MD to get more muscular } \\
(p<0.001)\end{array}$ & & & $\begin{array}{l}\text { The prevalence } \\
\text { rate of BDD was } \\
13.0 \% \text { in } \mathrm{M} \text { and } \\
21.7 \% \text { in } \mathrm{F} \text {. The } \\
\text { prevalence of MD } \\
\text { was } 12.7 \% \text { in } \mathrm{M} \\
\text { and } 4.2 \% \text { in } \mathrm{F} \\
\end{array}$ \\
\hline $\begin{array}{l}\text { Martínez et al. } \\
\text { (2014), Spain }\end{array}$ & $\begin{array}{l}\text { Descriptive } \\
\text { (MASS-S; diet } \\
\text { questions) }\end{array}$ & $\begin{array}{l}\text { Regular gym-goers, } M \\
(n=141) . \text { Age range: } \\
18-45 \text { years }\end{array}$ & $\begin{array}{l}\text { Daily protein intake was greater in } \\
\text { patients with MD compared to patients } \\
\text { without MD }\end{array}$ & & $\begin{array}{l}\text { Individuals with MD: } \\
\text { protein intake exceed the } \\
\text { limits proposed for } \\
\text { muscle mass } \\
\text { development }\end{array}$ & \\
\hline $\begin{array}{l}\text { Lin \& } \\
\text { DeCusati } \\
(2016) \text {, } \\
\text { United States }\end{array}$ & $\begin{array}{l}\text { Survey-based } \\
\text { (FRS; MASS) }\end{array}$ & $\begin{array}{l}\text { College students, } \mathrm{M} \\
(n=117) . \text { Age: } 19.89 \pm \\
1.17 \text { years }\end{array}$ & $\begin{array}{l}\text { M perceived distant and } M \text { peers as } \\
\text { having the most exaggerated preferences } \\
\text { for muscularity and that those } \\
\text { perceptions were not an accurate } \\
\text { reflection of their distant M peers' } \\
\text { reported preferences }\end{array}$ & $\begin{array}{l}\text { Perceptions of close F peer } \\
\text { muscularity preferences were } \\
\text { predictive of symptoms of MD, but } \\
\text { did not exist for other peer groups, } \\
\text { suggesting that the perceptions of } \\
\text { close F peer preferences may play a } \\
\text { role in the development of MD }\end{array}$ & & \\
\hline
\end{tabular}




\begin{tabular}{|c|c|c|c|c|c|c|}
\hline $\begin{array}{l}\text { Nieuwoudt et } \\
\text { al. (2015), } \\
\text { Australia }\end{array}$ & $\begin{array}{l}\text { Cross- } \\
\text { sectional } \\
\text { (MASS; } \\
\text { BDDQ; EAT- } \\
\text { 26) }\end{array}$ & $\begin{array}{l}\text { Weightlifters, } M \\
(n=648) . \text { Age: } 29.5 \pm \\
10.1 \text { years }\end{array}$ & $\begin{array}{l}\text { Significant correlations and associations } \\
\text { were detected between MD and BDD, } \\
\text { and MD and ED's }\end{array}$ & & & $\begin{array}{l}36 \text { participants } \\
(5.6 \%) \text { were at } \\
\text { risk of having } \\
\text { both MD and } \\
\text { BDD. This may } \\
\text { reflect a shared } \\
\text { pathogenesis } \\
\text { between MD, } \\
\text { BDD, and ED's }\end{array}$ \\
\hline $\begin{array}{l}\text { Griffiths et al. } \\
(2015) \text {, } \\
\text { Australia }\end{array}$ & $\begin{array}{l}\text { Descriptive } \\
\text { (character } \\
\text { descriptions; } \\
\text { positive } \\
\text { beliefs; EDE- } \\
\text { Q) }\end{array}$ & $\begin{array}{l}\text { Students, } \mathrm{M}(n=179) \\
\text { and } \mathrm{F}(n=313) . \text { Age: } \\
19.36 \pm 2.76 \text { years }\end{array}$ & $\begin{array}{l}\text { Positive beliefs about } \mathrm{AN} \text { and MD } \\
\text { significantly associated with more ED } \\
\text { symptoms for both M and F participants }\end{array}$ & $\begin{array}{l}\text { Among young M's and F's, positive } \\
\text { beliefs about AN and MD may } \\
\text { contribute to the development and } \\
\text { maintenance of these conditions }\end{array}$ & & $\begin{array}{l}\text { Authors link MD } \\
\text { strongly to AN } \rightarrow \\
\text { providing a } \\
\text { parallel with ED's }\end{array}$ \\
\hline $\begin{array}{l}\text { Hale et al. } \\
(2013), \text { United } \\
\text { States }\end{array}$ & $\begin{array}{l}\text { Cross- } \\
\text { sectional } \\
\text { (EDS; BDS; } \\
\text { MDI; DFT } \\
\text { scale) }\end{array}$ & $\begin{array}{l}\text { Weightlifters, } \mathrm{F}(n=74) \text {, } \\
\text { of which 'expert } \\
\text { bodybuilders' }(n=26), \\
\text { 'novice bodybuilders', } \\
(n=29) \text {, 'fitness lifters' } \\
(n=19) . \text { Age range: } 18 \text { - } \\
48 \text { years }\end{array}$ & & & $\begin{array}{l}\text { F bodybuilders seem to } \\
\text { be more at risk for } \\
\text { exercise dependence and } \\
\text { MD symptoms than F } \\
\text { recreational weight lifters }\end{array}$ & \\
\hline $\begin{array}{l}\text { Tod \& } \\
\text { Edwards } \\
\text { (2015), United } \\
\text { Kingdom }\end{array}$ & $\begin{array}{l}\text { Cross- } \\
\text { sectional } \\
\text { (BD and MS } \\
\text { subscales of } \\
\text { the MASS; } \\
\text { BIQLI; } \\
\text { BICSI) }\end{array}$ & $\begin{array}{l}\text { Participants, } M \\
(n=294) . \text { Age: } 20.5 \pm \\
3.1 \text { years }\end{array}$ & $\begin{array}{l}\text { Quality of life was correlated positively } \\
\text { with muscle satisfaction and } \\
\text { bodybuilding dependence but negatively } \\
\text { with body image coping }(p<0.05) \text {. Body } \\
\text { image coping was correlated positively } \\
\text { with bodybuilding dependence and } \\
\text { negatively with muscle satisfaction } \\
(p<0.05)\end{array}$ & & $\begin{array}{l}\text { Muscularity concerns } \\
\text { might influence body } \\
\text { image-related quality of } \\
\text { life }\end{array}$ & \\
\hline $\begin{array}{l}\text { Bo et al. } \\
(2014) \text {, } \\
\text { Italy }\end{array}$ & $\begin{array}{l}\text { Cross- } \\
\text { sectional } \\
\text { (ORTO-15; } \\
\text { MDDI; EAT- } \\
\text { 26) }\end{array}$ & $\begin{array}{l}\text { Students, M,F }(n=440) \\
\text { Age: } 19.8 \pm 1.96 \text { years }\end{array}$ & & $\begin{array}{l}\text { The prevalence of EDs, orthorexia, } \\
\text { and MD was } 9.1 \%, 25.9 \% \text {, and } \\
5.9 \% \text {. Those attending the Dietetics } \\
\text { school showed higher risk of EDs } \\
\text { and those from the Exercise and } \\
\text { Sport Sciences school higher MD }\end{array}$ & $\begin{array}{l}\text { Students with traits of } \\
\text { MD were more } \\
\text { frequently on diet or on } \\
\text { supplement use }\end{array}$ & \\
\hline
\end{tabular}




\begin{tabular}{|c|c|c|c|c|c|}
\hline $\begin{array}{l}\text { González- } \\
\text { Martí et al. } \\
\text { (2014), } \\
\text { Spain }\end{array}$ & $\begin{array}{l}\text { Cross- } \\
\text { sectional } \\
\text { (ESM; PSCQ) }\end{array}$ & $\begin{array}{l}\text { Weightlifters and } \\
\text { bodybuilders }(n=734), \\
\text { of whom } \mathrm{M}(n=562), \mathrm{F} \\
(n=172) . \text { Age: } 30.92 \pm \\
9.41 \text { years }\end{array}$ & $\begin{array}{l}\text { Muscle dissatisfaction and self-image } \\
(p<.01) \text { : Participants dissatisfied with } \\
\text { their muscles have devalued physical } \\
\text { perceptions, physical attractiveness and } \\
\text { PSC of themselves }\end{array}$ & & $\begin{array}{l}\text { Individuals suffering } \\
\text { from MD symptoms, } \\
\text { overall, have poorer PSC } \\
\text { perceptions }(p<.01)\end{array}$ \\
\hline $\begin{array}{l}\text { Thomas et al. } \\
\text { (2014), United } \\
\text { Kingdom }\end{array}$ & $\begin{array}{l}\text { Survey based } \\
\text { (DMAQ; } \\
\text { MDI; MASS- } \\
6 \text {; two scales } \\
\text { of muscular } \\
\text { perceptions) }\end{array}$ & $\begin{array}{l}\text { Weight training, } \mathrm{M} \\
(n=146) . \text { Age: } 22.8 \pm \\
5.0 \text { years }\end{array}$ & & $\begin{array}{l}\text { Perceived ideal physique predicted } \\
\text { MD through drive for muscularity, } \\
\text { and size/symmetry concerns and } \\
\text { physique protection through drive } \\
\text { for muscularity and social physique } \\
\text { anxiety }(p \leq 0.05)\end{array}$ & \\
\hline $\begin{array}{l}\text { Skemp et al. } \\
\text { (2013), United } \\
\text { States }\end{array}$ & $\begin{array}{l}\text { Cross- } \\
\text { sectional } \\
(\mathrm{MDI})\end{array}$ & $\begin{array}{l}\text { Competitive }(n=85), \\
\mathrm{M}(n=55), \mathrm{F}(n=30) \\
\text { and non-competitive }(n \\
=44), \mathrm{M}(n=24), \mathrm{F}(n \\
=24) \text { weight training } \\
\text { athletes. Age: } 31 \pm 12 \\
\text { years }\end{array}$ & & $\begin{array}{l}\text { Athletes focused on appearance } \\
\text { enhancement scored significantly } \\
\text { higher than athletes focused on } \\
\text { performance enhancement on all } 6 \\
\text { subscales }(p<0.01)\end{array}$ & $\begin{array}{l}\text { M scored significantly } \\
\text { higher than F on the } \\
\text { supplement, physique } \\
\text { protection, body size and } \\
\text { symmetry. Competitive } \\
\text { athletes scored } \\
\text { significantly higher than } \\
\text { noncompetitive athletes } \\
\text { did on diet, supplement, } \\
\text { exercise dependence, and } \\
\text { body size and symmetry } \\
(p<0.05)\end{array}$ \\
\hline $\begin{array}{l}\text { Compte et al. } \\
(2015) \text {, } \\
\text { Argentina }\end{array}$ & $\begin{array}{l}\text { Cross } \\
\text { sectional-two- } \\
\text { stage } \\
\text { epidemiologic } \\
\text { al } \\
\text { (EAT-26; } \\
\text { DMS-S; } \\
\text { MBAS-S; } \\
\text { RSE; SIAS; } \\
\text { PSWQ; EDE) }\end{array}$ & $\begin{array}{l}\text { University students, } M \\
(n=472) \text {. Age range: } \\
18-28 \text { years in } 90.4 \% \\
\text { of the total sample }\end{array}$ & $\begin{array}{l}\text { Students-MD relationship: Authors } \\
\text { identified possible MD in } 6.99 \%(n= \\
\text { 33) of the sample }\end{array}$ & & $\begin{array}{l}\text { Participants at risk of } \\
\text { MD were mainly } \\
\text { characterized by } \\
\text { disordered eating and } \\
\text { physical exercise. They } \\
\text { also had lower self- } \\
\text { esteem, higher anxiety in } \\
\text { social interaction and } \\
\text { greater use of food } \\
\text { supplements }\end{array}$ \\
\hline $\begin{array}{l}\text { Martínez et al. } \\
\text { (2014), Spain }\end{array}$ & $\begin{array}{l}\text { Survey based } \\
\text { (MASS-S; } \\
\text { BMI) }\end{array}$ & $\begin{array}{l}\text { Regular gym-goers, } \mathrm{M} \\
(n=141) . \text { Age range: } \\
18-45 \text { years }\end{array}$ & $\begin{array}{l}\text { Significant relationship between MD and } \\
\text { BMI }(p<0.05) \text {. MD identified in } 25 \% \text { of } \\
\text { the normal weight, } 33.3 \% \text { in overweight } \\
\text { and } 85.7 \% \text { in obese participants }\end{array}$ & & \\
\hline
\end{tabular}




\begin{tabular}{|c|c|c|c|c|c|c|}
\hline $\begin{array}{l}\text { Griffiths et al. } \\
(2014), \\
\text { Australia }\end{array}$ & $\begin{array}{l}2 \times 2 \times 2 \\
\text { between } \\
\text { subjects } \\
\text { design } \\
\text { (vignettes; } \\
\text { ASAB) }\end{array}$ & $\begin{array}{l}\text { Undergraduate students } \\
(n=343) \text { of which } \mathrm{M} \\
(n=113), \mathrm{F}(n=230) . \\
\text { Age range: } 16-40 \\
(19.24 \pm 2.9) \text { years }\end{array}$ & $\begin{array}{l}\text { F's with AN may be vulnerable to } \\
\text { stigmatization, especially by M's. AN } \\
\text { and MD are perceived as "F" and "M" } \\
\text { disorders, in line with societal gender } \\
\text { role expectations, and this stigmatization } \\
\text { is tied more strongly to perceptions of } \\
\text { sufferers' masculinity than femininity }\end{array}$ & & & \\
\hline $\begin{array}{l}\text { Hernández- } \\
\text { Martínez et al. } \\
\text { (2016), Spain }\end{array}$ & $\begin{array}{l}\text { Descriptive } \\
\text { and } \\
\text { correlational } \\
\text { (ESM; PSCQ; } \\
\text { Somatomorphi } \\
\text { c Matrix) }\end{array}$ & $\begin{array}{l}\text { Weightlifters, M } \\
(n=32) . \text { Age range: } 13- \\
40(23.22 \pm 7.99) \text { years }\end{array}$ & $\begin{array}{l}\text { Low PSC, substance use, and muscle } \\
\text { checking correlated with MD }(p<0.05)\end{array}$ & $\begin{array}{l}\text { Existence of body dissatisfaction } \\
\text { and muscle perception among } \\
\text { weightlifters that does not equate to } \\
\text { reality. Weightlifters use } \\
\text { substances, display obsessive } \\
\text { muscle checking behaviours, and } \\
\text { have low general PSC that stems } \\
\text { from their muscle (dis)satisfaction }\end{array}$ & & \\
\hline $\begin{array}{l}\text { Leone et al. } \\
\text { (2015), United } \\
\text { States }\end{array}$ & $\begin{array}{l}\text { Cross- } \\
\text { sectional } \\
\text { (MPDS; TAS- } \\
\text { 20; MDDI; } \\
\text { DMS) } \\
\end{array}$ & $\begin{array}{l}\text { Participants, } M \\
(n=304) . \text { Age: } 22.49 \pm \\
4.38 \text { years }\end{array}$ & & $\begin{array}{l}\text { Men with higher levels of } \\
\text { alexithymia are more likely to } \\
\text { report MD symptoms but not drive } \\
\text { for muscularity }\end{array}$ & & \\
\hline $\begin{array}{l}\text { Diehl \& } \\
\text { Baghurst } \\
\text { (2016), United } \\
\text { States }\end{array}$ & $\begin{array}{l}\text { Survey-based } \\
\text { (MDI; DMS; } \\
\text { BCS; } \\
\text { SATAQ-4) }\end{array}$ & $\begin{array}{l}\text { Personal trainers } \\
(n=1039), \mathrm{F}(63 \%), \mathrm{M} \\
(37 \%) . \text { Age: } 35.10 \pm \\
.38 \text { years }\end{array}$ & $\begin{array}{l}\text { A drive for muscularity and MD were } \\
\text { significantly, positively correlated with } \\
\text { internalization of thin ideals, } \\
\text { muscular/athletic ideals, family and peer } \\
\text { pressures, psychopathologic variables, } \\
\text { but not media pressures }\end{array}$ & $\begin{array}{l}\text { MD is less gender-specific in } \\
\text { personal trainers }\end{array}$ & & \\
\hline $\begin{array}{l}\text { Macik \& } \\
\text { Kowalska } \\
(2015), \text { Poland }\end{array}$ & $\begin{array}{l}\text { Cross- } \\
\text { sectional } \\
\text { (Pope } 1997 \\
\text { MD criteria; } \\
\text { ACL) }\end{array}$ & $\begin{array}{l}\text { Pope (1997) diagnosed } \\
\text { individuals with MD } \\
(n=30), \mathrm{M}(n=18), \mathrm{F} \\
(n=12) . \text { Age range: } 19- \\
55 \text { years }\end{array}$ & & & $\begin{array}{l}\text { Individuals with MD } \\
\text { have a negative self- } \\
\text { image and tend to not be } \\
\text { able to change them }\end{array}$ & $\begin{array}{l}\text { MD is supported } \\
\text { through BDD and } \\
\text { diagnostic criteria } \\
\text { set out at present }\end{array}$ \\
\hline $\begin{array}{l}\text { Laghi et al. } \\
\text { (2013), Italy }\end{array}$ & $\begin{array}{l}\text { Survey-based } \\
\text { (MASS) }\end{array}$ & $\begin{array}{l}\text { Adolescent } \\
\text { homosexuals, M ( } n=?) \text {. } \\
\text { Age range: } 15-19 \text { years }\end{array}$ & $\begin{array}{l}\text { MD correlated with self-disclosure of } \\
\text { family members and media pressure }\end{array}$ & $\begin{array}{l}\text { Adolescents (17-19 years) had the } \\
\text { highest mean scores on all } \\
\text { dimensions of the MASS, } \\
\text { compared with adolescents (15-16 } \\
\text { years) }\end{array}$ & & \\
\hline $\begin{array}{l}\text { Fabris et al. } \\
\text { (2017), Italy }\end{array}$ & $\begin{array}{l}\text { Online survey- } \\
\text { based }\end{array}$ & $\begin{array}{l}\text { Bodybuilders, } \mathrm{M} \\
(n=170) . \text { Age range: }\end{array}$ & & $\begin{array}{l}\text { Link between the risk of developing } \\
\text { MD and having an insecure }\end{array}$ & & \\
\hline
\end{tabular}




\begin{tabular}{|c|c|c|c|c|c|c|}
\hline & (MDDI; ASQ) & $\begin{array}{l}18-62(29.53 \pm 8.79) \\
\text { years }\end{array}$ & & $\begin{array}{l}\text { avoidant attachment style. This } \\
\text { finding suggests that non-optimal } \\
\text { relationships with caregivers early } \\
\text { in life can be a risk factor for } \\
\text { developing MD later in life }\end{array}$ & & \\
\hline $\begin{array}{l}\text { Collis et al. } \\
(2016) \\
\text { Australia }\end{array}$ & $\begin{array}{l}\text { Survey-based } \\
\text { (MDI; MBAS- } \\
\text { R; NPI-40) }\end{array}$ & $\begin{array}{l}\text { Participants, M } \\
(n=117) \text { included } \\
\text { current weight trainers } \\
(n=78), \text { former weight } \\
\text { trainers }(n=28), \text { never } \\
\text { weight trained }(n=11) \text {. } \\
\text { Age range: } 18-58 \\
(26.02 \pm 8.16) \text { years }\end{array}$ & $\begin{array}{l}\text { Male body attitudes were significantly } \\
\text { associated with indications of MD. No } \\
\text { significant association was found } \\
\text { between narcissism and MD }(p<.01)\end{array}$ & $\begin{array}{l}\text { Current weight trainers reported } \\
\text { more positive body attitudes than } \\
\text { former weight trainers. Former } \\
\text { weight trainers reported } \\
\text { significantly more negative body } \\
\text { attitudes compared with } \mathrm{M} \text { who } \\
\text { currently weight train if training } \\
\text { frequency was reported as once per } \\
\text { week or less }\end{array}$ & & \\
\hline $\begin{array}{l}\text { Baghurst et al. } \\
\text { (2014), United } \\
\text { States }\end{array}$ & $\begin{array}{l}\text { Online survey- } \\
\text { based } \\
\text { (MDI; } \\
\text { MAWI) }\end{array}$ & $\begin{array}{l}\text { Collegiate, } \mathrm{M}(n=114) \\
\text { Age: } 21.51 \pm 2.51 \\
\text { years }\end{array}$ & $\begin{array}{l}\text { Function and comfort were the most } \\
\text { cited reasons for clothing worn, although } \\
\text { upper body clothing elicited more } \\
\text { responses directed toward participants' } \\
\text { appearance }\end{array}$ & & $\begin{array}{l}\text { Physique protection } \\
\text { needs to be better defined } \\
\text { and understood before it } \\
\text { should be considered a } \\
\text { trait of MD }\end{array}$ & \\
\hline $\begin{array}{l}\text { Danilova et al. } \\
\text { (2013), United } \\
\text { States }\end{array}$ & $\begin{array}{l}\text { Online survey- } \\
\text { based } \\
\text { (MDI; BAS) }\end{array}$ & $\begin{array}{l}\text { Participants, M ( } n=77) \text {. } \\
\text { Age range: } 18-46 \text { years }\end{array}$ & & $\begin{array}{l}\text { M's approach MD from two } \\
\text { directions, those who see } \\
\text { themselves as too thin and want to } \\
\text { be more muscular, and those who } \\
\text { see themselves as too heavy and } \\
\text { want to be more muscular }\end{array}$ & $\begin{array}{l}\text { High-MD M displayed } \\
\text { significantly greater } \\
\text { distance between Actual } \\
\text { and Ideal Selves than did } \\
\text { low-MD M }\end{array}$ & \\
\hline $\begin{array}{l}\text { Menees et al. } \\
\text { (2013), United } \\
\text { States }\end{array}$ & $\begin{array}{l}\text { Online survey- } \\
\text { based } \\
\text { (MDQ; SHQ) }\end{array}$ & $\begin{array}{l}\text { Undergraduate } \\
\text { students, } M(n=118) . \\
\text { Age range: } 18-39 \\
(19.25 \pm 3.67) \text { years }\end{array}$ & $\begin{array}{l}\text { Significant relationships between } \\
\text { severity level of negative comment on } \\
\text { body and MD symptoms were found. } \\
\text { More negative reactions on comments } \\
\text { were associated with higher levels of } \\
\text { MD symptoms }\end{array}$ & $\begin{array}{l}\text { No significant differences were } \\
\text { found on MD symptoms between } \\
\text { participants who recalled comments } \\
\text { about their bodies and those who } \\
\text { did not recall such comments. }\end{array}$ & & \\
\hline $\begin{array}{l}\text { JIN Xinhong } \\
\text { et al. (2015), } \\
\text { China }\end{array}$ & $\begin{array}{l}\text { Cross- } \\
\text { sectional } \\
\text { (MASS; } \\
\text { BDDS; EAT; } \\
\text { IAS) }\end{array}$ & $\begin{array}{l}\text { Weightlifters, M } \\
(n=782) \text {. Age: ? }\end{array}$ & $\begin{array}{l}\text { MD and BDD, ED and social anxiety } \\
\text { were positively correlated }(\mathrm{P}<0.01) \text {, } \\
\text { showing a high rate of associated } \\
\text { morbidity }\end{array}$ & & & $\begin{array}{l}\text { BDD, ED and } \\
\text { social anxiety } \\
\text { have a certain } \\
\text { predictive effect } \\
\text { on MD, but the } \\
\text { prediction was } \\
\text { limited }\end{array}$ \\
\hline
\end{tabular}




\begin{tabular}{|c|c|c|c|c|c|c|}
\hline $\begin{array}{l}\text { Nieuwoudt et } \\
\text { al. (2016), } \\
\text { Australia }\end{array}$ & $\begin{array}{l}\text { Mixed } \\
\text { methods } \\
\text { (MASS; one- } \\
\text { on-one } \\
\text { interview) }\end{array}$ & $\begin{array}{l}\text { Resistance trainers, } \mathrm{M} \\
(n=48) \text {. Age: } 18 \rightarrow \\
\text { years }\end{array}$ & & $\begin{array}{l}\text { MD represented a syndrome of } \\
\text { frequently co-occurring symptoms; } \\
\text { there was a significant probability } \\
(>.70) \text { of a participant with one } \\
\text { diagnostic symptom of MD } \\
\text { (criterion } 2 \text { a or } 3 \text { ) to exhibit another } \\
\text { symptom (criterion } 1 \text { ) of MD }\end{array}$ & & $\begin{array}{l}\text { The study } \\
\text { provides some } \\
\text { evidence to } \\
\text { question the } \\
\text { acceptance of the } \\
\text { proposed MD } \\
\text { criteria }\end{array}$ \\
\hline $\begin{array}{l}\text { Longobardi et } \\
\text { al. (2017), } \\
\text { Italy }\end{array}$ & $\begin{array}{l}\text { Cross- } \\
\text { sectional } \\
\text { (MDDI; SCL- } \\
\text { 90-R; DES-II }\end{array}$ & $\begin{array}{l}\text { Bodybuilders, } M \\
(n=145) \text {. Age: } 30 \pm 9.1 \\
\text { years }\end{array}$ & $\begin{array}{l}\text { The Competitiveness dimension and } \\
\text { AAS intake not related to MD, while age } \\
\text { appeared to be more significant }\end{array}$ & $\begin{array}{l}\text { Bodybuilders at risk of MD display } \\
\text { greater global psychopathology and } \\
\text { present higher scores on all SCL- } \\
\text { 90-R dimensions when compared to } \\
\text { not at risk bodybuilders of MD }\end{array}$ & & \\
\hline $\begin{array}{l}\text { Schneider et } \\
\text { al. (2017), } \\
\text { Germany }\end{array}$ & $\begin{array}{l}\text { Experimental } \\
\text { (MDI items } 6 \\
\text { and } 11 \text {; MDDI } \\
\text { items } 17 \text { and } \\
18)\end{array}$ & $\begin{array}{l}\text { Physically active, } \mathrm{M} \\
(n=100) . \text { Age: } 24.2 \pm \\
3.8 \text { years }\end{array}$ & $\begin{array}{l}\text { Social withdrawal associated with social } \\
\text { comparison tendencies }\end{array}$ & & $\begin{array}{l}\text { M with risk of MD } \\
\text { showed lesser desire for } \\
\text { social interaction than M } \\
\text { with no risk, which can } \\
\text { be seen as a risk factor } \\
\text { for psychopathological } \\
\text { outcomes }\end{array}$ & \\
\hline $\begin{array}{l}\text { Mitchell et al. } \\
\text { (2017), } \\
\text { Australia }\end{array}$ & $\begin{array}{l}\text { Cross- } \\
\text { sectional } \\
\text { (MDDI; EAT- } \\
\text { 26) }\end{array}$ & $\begin{array}{l}\text { Natural bodybuilders, } \\
\text { M }(n=60) . \text { Age: } 29.6 \pm \\
7.1 \text { years }\end{array}$ & $\begin{array}{l}\text { ED scores, rate of pre-competition } \\
\text { weight loss and number of competitions } \\
\text { were significant predictors of MD. EAT- } \\
26 \text { and MDDI associated and } \\
\text { underscores the salience of disordered } \\
\text { eating pathology in presentations of MD }\end{array}$ & & & $\begin{array}{l}\text { Authors compare } \\
\text { MD with ED and } \\
\text { confirms the } \\
\text { association }\end{array}$ \\
\hline $\begin{array}{l}\text { González- } \\
\text { Martí et al. } \\
\text { (2017), Spain }\end{array}$ & $\begin{array}{l}\text { Descriptive } \\
\text { (ESM, SM) }\end{array}$ & $\begin{array}{l}\text { Bodybuilders and } \\
\text { weightlifters, M } \\
(n=562), \mathrm{F}(n=172) . \\
\text { Age range: } 16-62 \text { years }\end{array}$ & $\begin{array}{l}\text { MD associated with AAS use. } 50 \% \text { of M } \\
\text { and F participants used or had used AAS }\end{array}$ & & & \\
\hline
\end{tabular}

Mean \pm standard deviations, AAS = anabolic androgenic steroids;

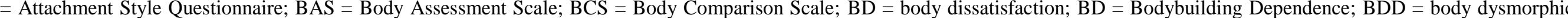

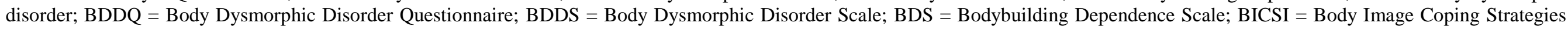

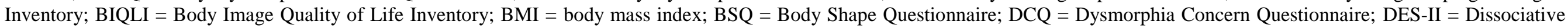

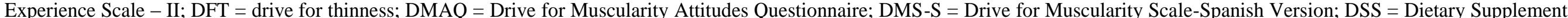

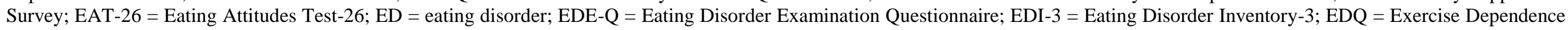

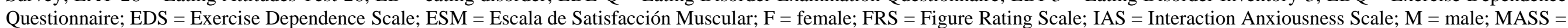

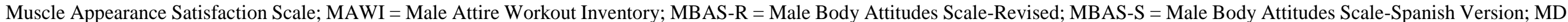

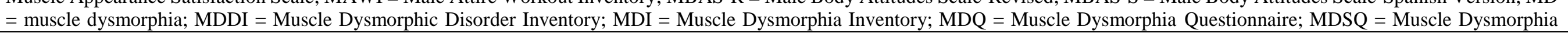




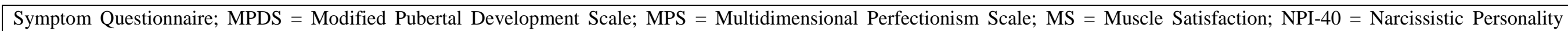

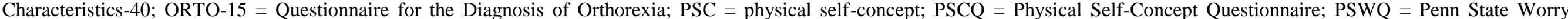

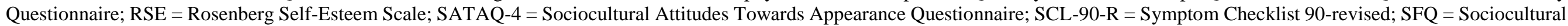

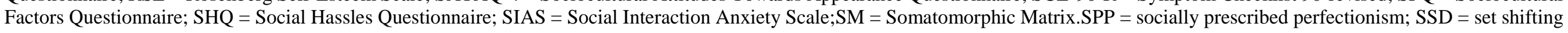
difficulties; TAS-20 = Toronto Alexithymia Scale-20 item. 